\title{
Role of atrial natriuretic peptide (ANP) in the regulation of insulin secretion and vitality of pancreatic ß cells
}

\author{
Sabine Tauscher ${ }^{1 * \dagger}$, Hitoshi Nakagawa ${ }^{2 \dagger}$, Katharina Völker ${ }^{1}$, Birgit Gaßner ${ }^{1}$, Saskia Pröhl', Michaela Kuhn \\ From 7th International Conference on cGMP Generators, Effectors and Therapeutic Implications \\ Trier, Germany. 19-21 June 2015
}

\section{Background}

The cardiac hormone atrial natriuretic peptide (ANP) increases intracellular cyclic GMP levels via activation of the guanylyl cyclase-A (GC-A) receptor and exerts important endocrine effects regulating arterial blood pressure and intravascular volume. Besides these wellknown effects, several studies suggest a role for ANP and its receptor in the endocrine pancreas. For instance, ANP infusion enhanced insulin plasma levels in healthy subjects [1]. Even more low plasma ANP levels predict the development of diabetes type II [2]. Also it has been shown that ANP can stimulate the function and the growth of cultured pancreatic $ß$ cells [3,4]. Since these studies were conducted with synthetic ANP, the question remains whether the endogenous ANP/GC-A system modulates insulin secretion or the growth and vitality of pancreatic $\beta$ cells under (patho)physiological conditions. Therefore, here we generated and studied a novel mouse model with conditional, cell-restricted deletion of the GC-A receptor in cells $\left(\mathrm{GC}-\mathrm{A}^{\mathrm{f} / \mathrm{fl}}\right.$;Rip-Cre ${ }^{+/}$: B GC-A KO mice). The Rip-Cre mouse line was provided by Dr. Pedro Herrera [5]. The GC-A ${ }^{\mathrm{fl} / \mathrm{fl}}$ mice were previously generated in our group [6].

\section{Methods and results}

Our first aim was to characterize whether ANP modulates $ß$ cell vitality and function under pathological conditions of insulin resistance. Five weeks old B GC-A KO and control littermates were fed with a high-fat $(60 \%$ energy from fat, HFD) versus a normal diet (10\% energy from fat, ND) during 3 months. The HFD induced a

\footnotetext{
* Correspondence: sabine.tauscher@uni-wuerzburg.de

+ Contributed equally

'Institute of Physiology, University of Würzburg, Würzburg, Germany

Full list of author information is available at the end of the article
}

genotype-independent increase in body weight, arterial blood pressure and fasted blood glucose levels. Moreover, all mice showed a pathological oral glucose tolerance test (oGTT), confirming an insulin resistant state. In control mice, immunostainings of insulin and morphometrical analyses showed an increase in the islet area, the total area of $\beta$ cells per islet and in the number of $\beta$ cells per islet after HFD. Since the area of single $B$ cells remained the same under ND and HFD, these results demonstrate that the observed increase in $\beta$ cell mass was caused by $B$ cell proliferation and not by hypertrophy. Strikingly, $B$ cell proliferation in response to HFD-provoked insulin resistance was abolished in $B$ GC-A KO mice.

As mentioned above, low plasma levels of ANP predict development of future diabetes and glucose progression in the elderly, suggesting a (co)causal role of deficient ANP/ GC-A signalling in diabetes development [2]. To study whether chronic $B$ cell ANP/GC-A dysfunction alters insulin-dependent glucose homeostasis, we analyzed female $ß$ GC-A KO and control mice at 10-15 months of age. Fasted insulin plasma levels were not different between genotypes. Surprisingly, the oGTT showed a better glucose handling in the $\mathrm{B} \mathrm{GC-A} \mathrm{KO} \mathrm{mice,} \mathrm{with} \mathrm{lower}$ plasma glucose levels at all time-points and a significantly lower area under the curve (AUC). Insulin sensitivity was not different between genotypes. However, glucose-stimulated insulin release was enhanced in the B GC-A KO mice.

\section{Conclusions}

Our data indicate that ANP/GC-A signalling contributes to enhanced $\beta$-cell proliferation in situations of insulin resistance, for instance under HFD. The molecular mechanism of the improved glucose-dependent insulin 
secretion in the older $B$ GC-A KO mice is being addressed in our current investigations. Our study contributes to the recent appreciation of the metabolic roles of ANP and suggests an endocrine axis between the heart and the endocrine pancreas.

\section{Acknowledgement}

This work was supported by the DFG (DFG KU1037/5-1).

\section{Authors' details}

${ }^{1}$ Institute of Physiology, University of Würzburg, Würzburg, Germany. ${ }^{2}$ First

Department of Internal Medicine, Nara Medical University, Kashihara, Japan.

Published: 2 September 2015

\section{References}

1. Uehlinger DE, Weidmann P, Gnadinger MP, Hasler L, Bachmann C, Shaw S, et al: Increase in circulating insulin induced by atrial natriuretic peptide in normal humans. J Cardiovasc Pharmacol 1986, 8(6):1122-1129.

2. Magnusson M, Jujic A, Hedblad B, Engstrom G, Persson M, Struck J, et al: Low plasma level of atrial natriuretic peptide predicts development of diabetes: the prospective Malmo Diet and Cancer study. J Clin Endocrinol Metab 2012, 97(2):638-645.

3. Ropero AB, Soriano S, Tuduri E, Marroqui L, Tellez N, Gassner B, et al: The atrial natriuretic peptide and guanylyl cyclase-A system modulates pancreatic beta-cell function. Endocrinology 2010, 151(8):3665-3674.

4. You H, Laychock SG: Atrial natriuretic peptide promotes pancreatic islet beta-cell growth and Akt/Foxo1a/cyclin D2 signaling. Endocrinology 2009, 150(12):5455-5465.

5. Herrera PL: Adult insulin- and glucagon-producing cells differentiate from two independent cell lineages. Development 2000 127(11):2317-2327.

6. Holtwick R, Gotthardt M, Skryabin B, Steinmetz M, Potthast R, Zetsche B, et al: Smooth muscle selective deletion of guanylyl cyclase-A prevents the acute but not chronic effects of ANP on blood pressure. Proc Natl Acad Sci USA 2002, 99(10):7142-7147.

doi:10.1186/2050-6511-16-S1-A92

Cite this article as: Tauscher et al:: Role of atrial natriuretic peptide (ANP) in the regulation of insulin secretion and vitality of pancreatic B cells. BMC Pharmacology and Toxicology 2015 16(Suppl 1):A92.

\section{Submit your next manuscript to BioMed Central and take full advantage of:}

- Convenient online submission

- Thorough peer review

- No space constraints or color figure charges

- Immediate publication on acceptance

- Inclusion in PubMed, CAS, Scopus and Google Scholar

- Research which is freely available for redistribution

Submit your manuscript at www.biomedcentral.com/submit
Biomed Central 